\title{
Treatment and reuse of toilet wastewater by an airlift external circulation membrane bioreactor
}

\author{
Yaobo Fan *, Gang Li, Linlin Wu, Wenbo Yang, Chunsong Dong, Huifang Xu, Wei Fan \\ Research Center for Eco-Environmental Sciences, Chinese Academy of Sciences (CAS), P.O. Box 2871, Beijing 100085, PR China
}

Received 4 July 2005; received in revised form 27 January 2006; accepted 31 January 2006

\begin{abstract}
Membrane bioreactor (MBR) is a high efficient technology for toilet wastewater treatment and reuse. Practical performance of a full-scale airlift external circulation membrane bioreactor (AEC-MBR) for toilet wastewater treatment was investigated. The results showed that the removals of $\mathrm{COD}, \mathrm{BOD}_{5}, \mathrm{NH}_{4}-\mathrm{N}$, color and turbidity were $90 \%, 99 \%, 95 \%, 80 \%$ and $99.7 \%$, respectively, with the average effluent quality of COD $24 \mathrm{mg} / \mathrm{L}$, $\mathrm{BOD}_{5} 2.4 \mathrm{mg} / \mathrm{L}, \mathrm{NH}_{4}-\mathrm{N} 5 \mathrm{mg} / \mathrm{L}$, color $30^{\circ}$ and turbidity $0.2 \mathrm{NTU}$. Abundant microorganisms could live well and play an important role in sludge health and in well performance of the MBR, because without circulation pump in the system. The maximum flux was maintained stably at $13.5 \mathrm{~L} /$ $\mathrm{m}^{2}$ on the TMP at 4-9 $\mathrm{kPa}$ for more than 5 months. The energy consumption of the AEC-MBR system was at $0.32-0.64 \mathrm{kWh} \mathrm{m}^{-3}$ and the operational cost was about $\$ 0.11 / \mathrm{m}^{3}$. More than 15 sets of AEC-MBR systems were applied successfully for toilet wastewater treatment and reuse in China in recent years.
\end{abstract}

(C) 2006 Published by Elsevier Ltd.

Keywords: Toilet wastewater treatment; Membrane bioreactor (MBR); Removal efficiency; Low energy consumption; Water reuse

\section{Introduction}

With population increasing in cities, toilet wastewater (or black water) becomes an attracted problem. Untreated toilet wastewater pollutes rivers and makes them lose functions of water resources or leads to dangerous epidemic diseases.

The first water closet was founded in 1852 in London. It is a great invention of mankind in the 19th century. However, the water closets result in a kind of wastewater, the toilet wastewater or the black water $[1,2]$. Toilet wastewater is characterized by a high concentration of organic matter. Very elevated values for suspended solids, uncountable numbers of microorganism such as faecal bacteria and high value of the BOD shows that this kind of liquid is very harmful for the environment. It has to be treated to meet the wastewater discharge standards [3]. Eighty to $90 \%$ of ammonia or phosphorus and $50-57 \%$ of organic pollutants in domestic wastewater come from toilet wastewater. In general, a person will discharge 400-500 1 urine, 501 night soil and consume

\footnotetext{
* Corresponding author. Tel.: +8610628 491 09; fax: +861629 23563 .

E-mail addresses: ybfan@mail.rcees.ac.cn (Y. Fan),

ligang7786@hotmail.com (G. Li).
}

150001 fresh water per year. The discharge of toilet wastewater is up to 14.4 million tons per day from the cities in China. One tonne of toilet wastewater can pollute $220 \mathrm{t}$ of clean water [2]. However, lots of toilets water is discharged directly to the wastewater treatment plants or surface water bodies without treatment. As a consequence, it not only wastes a great deal of fresh water but also results in serious water pollution [4].

As the situation of water shortage and pollution is more and more serious in cities, it is very important to develop high efficient technologies for toilet wastewater treatment and reuse. Membrane bioreactor (MBR) is one of the available high efficient technologies to treat this kind of wastewater. Smith et al. firstly studied MBR to treat wastewater over 30 years ago [5]. In recent years, MBRs are received increasing attention because of their advantages in wastewater treatment and reuse, such as high effluent qualities, free of bacteria, compact plant configuration, high values of sludge age and low sludge production, etc. [5,6]. In 1986, a kind of MBR system was used firstly to treat night soil in Japan [7]. Some MBR systems were successfully used on cruise ships to treat toilet wastewater and gray water, such as the Copa MBR Technology ${ }^{\circledR}$ and the ZeeWeed ${ }^{\mathbb{R}}$ MBR of ZENON's system [8-10]. However, the articles on treatment and reuse of toilet wastewater with MBRs are very few. 
MBRs can be classified into two major groups according to their configuration, the external MBRs and the submerged MBRs, commercially available for the treatment of domestic and industrial wastewater. Of the external MBRs, one is the cross-flow membrane bioreactor, in which the mixed liquor is circulated with a circulation pump. High-energy consumption of the circulation pump made this type of membrane bioreactor less attractive to users [11]. Compared to the cross-flow MBR, the submerged MBR become major one applied in wastewater treatment, because of its low operation cost [12]. However, the operation of membrane's cleaning or maintaining is always difficult in the submerged MBR, because it cannot be done on line very well.

An ideal MBR should be lower energy consumption and maintained easily. In studying of this kind MBR, a novel MBR named airlift external circulation membrane bioreactor (AECMBR) had been developed and was used to treat toilets wastewater for reuse. AEC-MBR has the advantages both with the conventional cross-flow MBRs and with the submerged MBRs. There was no recycling pump in AEC-MBR, so the energy consumption and operation cost was lower. The membrane cleaning or maintaining could be done on line or only in the membrane tank without interfering with aeration tank.

Since 2000, Xu and Fan studied on the treatment and reuse of toilet wastewater by an AEC-MBR. A significant result was made as that the effluent of the MBR was stable with COD $<47 \mathrm{mg} / \mathrm{L}, \quad$ BOD $_{5}<8.5 \mathrm{mg} / \mathrm{L}, \quad$ ammonia $<20 \mathrm{mg} / \mathrm{L}$, when the influent concentrations of $\mathrm{COD}, \mathrm{BOD}_{5}$ and $\mathrm{NH}_{3}-\mathrm{N}$ were 440-980, 360-612 and 59-111 mg/L, respectively [13]. However, the MBR studied was very limited on a scale of 1-2 $t$ / $\mathrm{d}$, with a very low membrane flux from $3-5 \mathrm{~L} / \mathrm{m}^{2} \mathrm{~h}$. The removal efficiency of color was quite low, so that the reused rate of the treated toilet wastewater was very difficult to be increased to a satisfaction level. Moreover, further research is need to be done on optimum of operating conditions for membrane fouling control and for decrease of energy consumption.
To solve the problems above, a new type on a full-scale AEC-MBR system for toilet wastewater treatment and reuse was set and studied. The purpose of this paper is to exam the performance of the new MBR, to improve the efficiency of pollutant removal, to optimize the operating parameters and conditions, to increase the reuse rate of the treaded wastewater, and finally to give an analysis of the energy consumption and operating cost of the MBR.

\section{Materials and methods}

\subsection{System description}

Fig. 1 shows the new AEC-MBR system. A full-scale system with a capability of $10 \mathrm{~m}^{3} / \mathrm{d}$ was installed at a public toilet in Jing-Shan Park in Beijing, China.

The system mainly consisted of four components, adjustment tank, aeration tank, membrane tank and effluent tank with working volume of 3.4, 6.8, 1.8, $6.7 \mathrm{~m}^{3}$, respectively. From septic tank, the raw toilet wastewater flowed through an acidification tank with filling materials in to the adjustment tank. A level sensor fixed at the membrane tank was used to switch the feed pump at the adjustment tank on and off to feed wastewater to the MBR to maintain a giving water level of it. Four hollow fiber membrane modules were mounted in the membrane tank. In the AEC-MBR, a H-type recycling pipe was invented, which is fixed between the aeration tank and the membrane tank. Through the H-type recycling pipe, the mixed liquor flowed from the bottom of aeration tank to that of the membrane tank, and then the mixed liquor flowed back to the aeration tank over the clapboard of the two tanks. H-type recycling pipe does not need valve and valve well. When the membrane cleaning is need by water or chemical reagent, the membrane tank can be separated from aeration tank simply by lowering the water level of MBR. And then, the membrane maintaining operation can be done at the membrane tank. Because of the recycling pipe, sometimes this MBR was called H-type recycling pipe airlift external circulation membrane bioreactor. The flow of mixed liquid was driven by air blown from the aeration pipes under the membrane modules. As a result, a circulation flow of 20 times to the membrane effluent was formed. Except to make a circulation flow, the airflow in the membrane tank created a shear force to scour membrane fibers to control the membrane fouling. And in addition, in this condition, the dissolve oxygen in the bioreactor could keep at 1.0-2.0 mg/ L. The effluent was drawn from the membrane modules and then sent the reclaimed water tank by a suction pump. A vacuum meter was mounted on the inlet pipe of the suction pump to monitor the trans-membrane pressure (TMP). The total filtration area of four hollow fiber membrane modules was $40 \mathrm{~m}^{2}$. The specifications of the membrane are shown in Table 1.

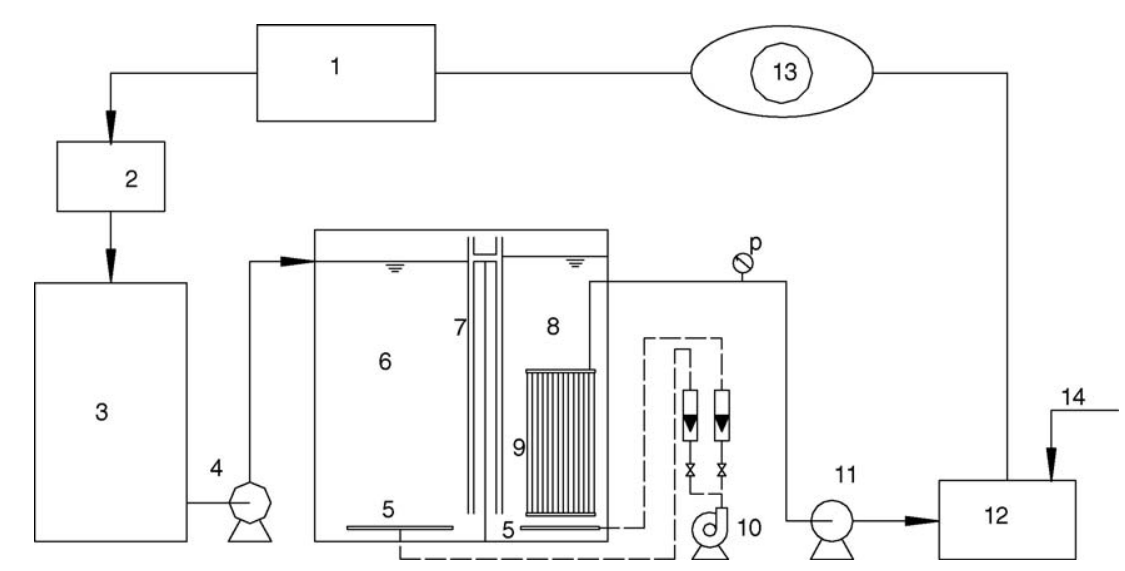

Fig. 1. Schematic diagram of the full-scale MBR system for toilet wastewater treatment: (1) septic tank; (2) acidification tank; (3) adjustment tank; (4) feed pump; (5) aeration pipe; (6) aeration tank; (7) H-type recycling pipe; (8) membrane tank; (9) membrane module; (10) air compressor; (11) suction pump; (12) reclaimed water tank; (13) toilet bowl; (14) tap water. 
Table 1

Specifications of the hollow membrane module
Membrane material

Pore size $(\mu \mathrm{m})$

Membrane area $\left(\mathrm{m}^{2}\right)$

TMP (MPa)

Manufacturer
Polyvinylidene fluoride (PVDF) 0.2

40

$\leq 0.04$

Tianjing Motimo Membrane

Technology Ltd., China
Table 2

The methods and instruments used for experimental analysis

\begin{tabular}{ll}
\hline Parameters & Methods and instruments \\
\hline COD & CTL-12 COD meter (Huatong Company, China) \\
BOD $_{5}$ & BOD Trak ${ }^{\mathrm{TM}}$ (Hach Company, USA) \\
$\mathrm{NH}_{4}-\mathrm{N}$ & Nessler's reagent colorimetric method $_{\text {Color }}$ \\
Turbidity & Determination of visual colorimetric method \\
& Bench Lp2000 turbidity meter \\
Dissolved oxygen (DO) & (Hunna Instruments, USA) \\
pH & Models 810 Orion complus dissolved oxygen meter \\
MLSS & pH meter (pHB-4, China) \\
Viscosity & Weight method [9] \\
\hline
\end{tabular}

\subsection{Analytical methods}

The performance of the ACE-MBR system was monitored by analyzing the parameters of $\mathrm{COD}, \mathrm{BOD}_{5}, \mathrm{NH}_{4}-\mathrm{N}$, color, turbidity, DO, $\mathrm{pH}, \mathrm{MLSS}$, and viscosity. The samples were taken from influent, mixed liquid and effluent of the MBR. The methods and instruments adopted for the parameter analysis are shown in Table 2.

\subsection{The characteristics of toilets wastewater}

Table 3 reveals the characteristics of the toilet wastewater, the influent, to the AEC-MBR.

\section{Results and discussion}

\subsection{Removal of organic contaminants}

Fig. 2 indicates the variations of COD in the influent and effluent of the MBR and COD removal efficiency during the experiment time. At the beginning of system operation, the COD of effluent was relatively high and varied from 89 to $73 \mathrm{mg} / \mathrm{L}$ with MLSS growing from 2.0 to $3.3 \mathrm{~g} / \mathrm{L}$. After 30 days, with MLSS up to $3.5-7.3 \mathrm{~g} / \mathrm{L}$, the COD in effluent declined under $50 \mathrm{mg} / \mathrm{L}$ and at an average $24 \mathrm{mg} / \mathrm{L}$. In the experiment, the removal efficiency of COD varied from $70 \%$ to $99 \%$ and with an average of $90 \%$, despite of the seasonal fluctuation of COD from 363 to $603 \mathrm{mg} / \mathrm{L}$ in the influent.

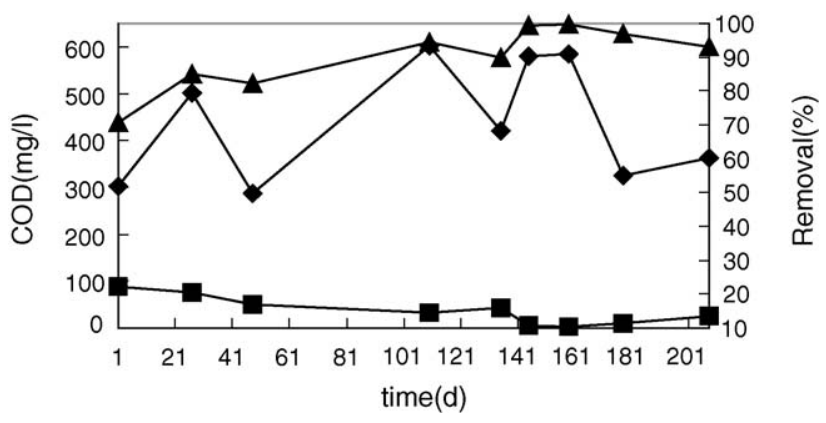

Fig. 2. Variations and removal of COD: removal.

Fig. 3 shows the variations and removal efficiency of $\mathrm{BOD}_{5}$. Despite of the fluctuation of $\mathrm{BOD}_{5}$ in influent from 100 to $260 \mathrm{mg} / \mathrm{L}$, the $\mathrm{BOD}_{5}$ in effluent was below $6 \mathrm{mg} / \mathrm{L}$, at an average $2.4 \mathrm{mg} / \mathrm{L}$ and with an average removal of $98.6 \%$. Therefore, a high $\mathrm{BOD}_{5}$ removal was gotten in the experiment, the possible reason was that the sludge load in this system was quite low at $0.01-0.04 \mathrm{~kg} \mathrm{BOD}_{5} / \mathrm{kg}$ MLSS, with average $0.02 \mathrm{~kg} \mathrm{BOD}_{5} / \mathrm{kg}$ MLSS, according to the calculation of sludge load on $\mathrm{BOD}_{5}$.

\subsection{Removal of $\mathrm{NH}_{4}-\mathrm{N}$}

The raw toilet wastewater had a low ratio of carbon to nitrogen $(\mathrm{C} / \mathrm{N})$, as the $\mathrm{BOD}_{5} / \mathrm{NH}_{4}-\mathrm{N}$ was about $2 / 1$ on average shown in Table 3. How to get a high removal of $\mathrm{NH}_{4}-\mathrm{N}$ was studied in the experiment. It was found that if alkalinity was added in the bioreactor with 2 times of the quantity of $\mathrm{NH}_{4}-\mathrm{N}$ in influent, a satisfying removal of $\mathrm{NH}_{4}-\mathrm{N}$ could be made. Why the adding of alkalinity was much lower than that of 7.14 times of $\mathrm{NH}_{4}-\mathrm{N}$ in theory? Through the research to find the reason, it was found that there was alkalinity, 5.2 times of $\mathrm{NH}_{4}-\mathrm{N}$ in influent and circulated in the MBR system. Under the condition of proper alkalinity adding, MLSS $2.0-7.3 \mathrm{~g} / \mathrm{L}$ and DO 1.0 $2.0 \mathrm{mg} / \mathrm{L}$, the concentration of $\mathrm{NH}_{4}-\mathrm{N}$ in effluent was decreased below $10 \mathrm{mg} / \mathrm{L}$, with an average of $4.72 \mathrm{mg} / \mathrm{L}$, and an average removal efficiency of $95 \%$ was gotten, when the $\mathrm{NH}_{4}-\mathrm{N}$ of influent varied from 78.3 to $129.5 \mathrm{mg} / \mathrm{L}$, with the average of $103.2 \mathrm{mg} / \mathrm{L}$. The performance of $\mathrm{NH}_{4}-\mathrm{N}$ removal was shown in Fig. 4.

\subsection{Color removal performance}

The toilet wastewater was a kind of feculent liquid with yellow color varied from $100^{\circ}$ to $150^{\circ}$. Because the substances causing color in wastewater were difficult to be biodegraded and were easy to permeate though membrane, the effluent of

Table 3

Characteristics of toilet wastewater

\begin{tabular}{llllllll}
\hline Parameters & $\mathrm{COD}(\mathrm{mg} / \mathrm{L})$ & $\mathrm{BOD}_{5}(\mathrm{mg} / \mathrm{L})$ & $\mathrm{NH}_{4}-\mathrm{N}(\mathrm{mg} / \mathrm{L})$ & Color $\left({ }^{\circ}\right)$ & Turbidity $(\mathrm{NTU})$ & $\mathrm{pH}$ & $\mathrm{Temperature}\left({ }^{\circ} \mathrm{C}\right)$ \\
\hline Max. & 602 & 363 & 129.5 & 150 & 217 & 8.46 & 25.1 \\
Min. & 363 & 160 & 18.25 & 100 & 40.55 & 7.47 & 14.2 \\
Average & 440 & 197 & 103.2 & 120 & 115.9 & 8.00 & 21.1 \\
\hline
\end{tabular}




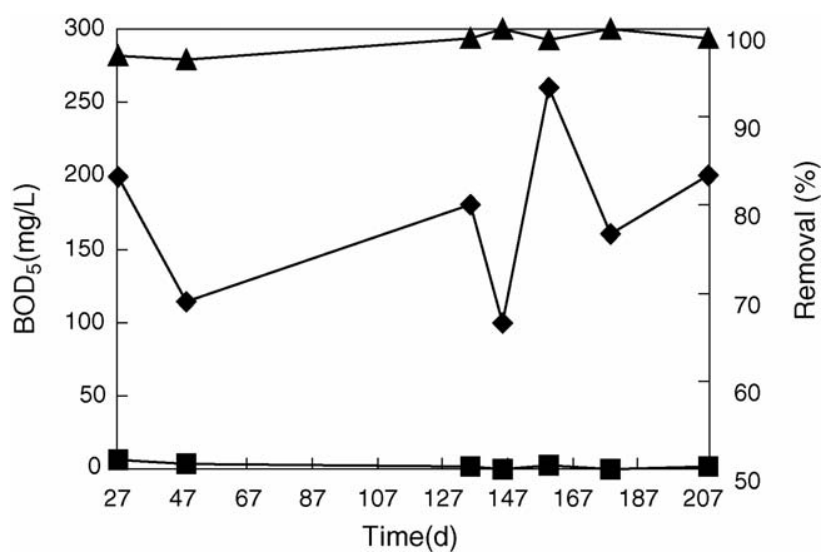

Fig. 3. Variations and removal efficiency of $\mathrm{BOD}_{5}$ : $(\bullet)$ influent; $(\boldsymbol{\square})$ effluent; $(\boldsymbol{A})$ removal.

MBR was always with the distinctive and unsatisfactory color. In addition, the cumulating of color was another serious problem in the water reuse system. Low removal efficiency of color was directly impacted the application of the AEC-MBR in toilet wastewater treatment and reuse.

In order to remove the color from the tread water, the characteristics of the matters causing color in the permeated water were studied. The efficiencies of seven decolorizing techniques were measured, as that of electrochemistry, chemical oxidation, flocculation, ultra-filtration, filtration with granular activated carbon and adsorption of powder activated carbon (PAC). It was found that adsorption by PAC was more effective and economical than the others. To select the PAC with the optimum property to decolorize reuse water reclaimed from toilet wastewater, the relationships between the decolorizing efficiency and adsorption indexes were studied. Two indexes for chosen activated carbon were tested, and from five kinds of PAC, two PAC with high decolorizing efficiency were selected. With the use of the selected PAC, the effluent color could be reduced to a desire level by adding an acceptable dose of PAC. Under the condition of PAC adding, the parameter, dilution factor of color, could be controlled less than $30^{\circ}$. The color removal was increased from $20 \%$ to $80 \%$ (Fig. 5). On the increasing of the color removal, the reuse rate of treated wastewater rose from $30.0 \%$ to $76.0 \%$.

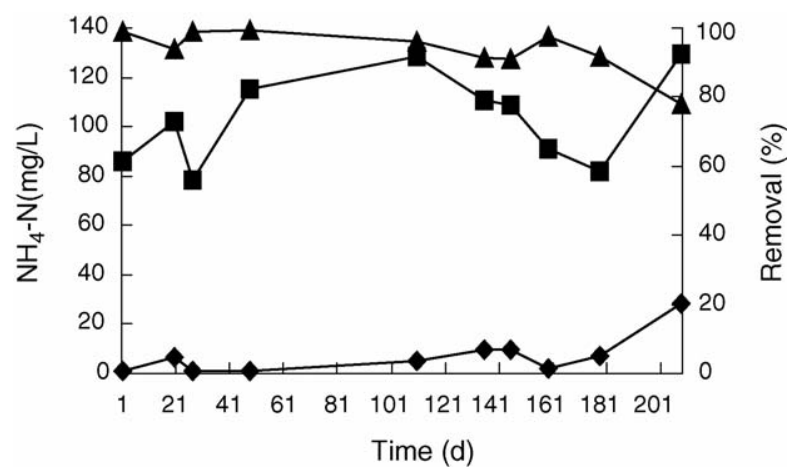

Fig. 4. Variation and removal efficiency of $\mathrm{NH}_{4}-\mathrm{N}$ : ( $\left.\boldsymbol{\square}\right)$ influent; ( $\bullet$ ) effluent; (A) removal.

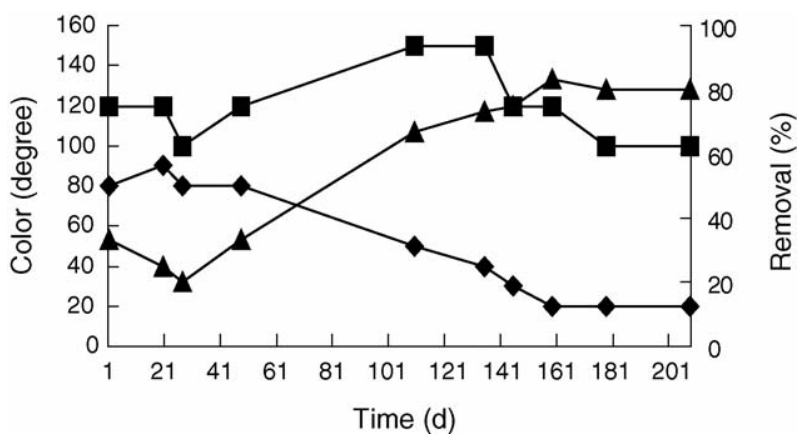

Fig. 5. Variation and removal of color: influent; effluent; removal.

According to the experiment result, to make the reuse water meet the reuse standard of color, the consumption of PAC was less than $20 \mathrm{~g}-50 \mathrm{~g} / \mathrm{m}^{3}$ and the cost was at $\$ 0.02 / \mathrm{m}^{3}$. This result illustrates that the AEC-MBR with decolorizing by selected $\mathrm{PAC}$ is a very practical technique for toilet wastewater reclamation and reuse.

\subsection{Turbidity removal performance}

Although the turbidity of the influent was high and fluctuation, varying between 40 and 217 NTU during the whole experiment, due to the excellent ability of separation of the membrane, the effluent turbidity maintained consistently less than 1.0 NTU with an average 0.2 NTU and the turbidity removal was up to $99.7 \%$, as shown in Fig. 6.

\subsection{MLSS and circulation ratio}

Fig. 7 shows the growth of MLSS (mixed liquor suspended solids) in the system and the circulation ratio between the bioreactor and membrane tank by airlift. During the first 20 days, at the start-up stage of the MBR system, MLSS had no increase but decreased from 3.2 to $2.0 \mathrm{~g} / \mathrm{L}$ in the bioreactor, as a phenomenon for cultivation of the seeding sludge. After 20 days and with the operation time of the system, the MLSS increased from 2.0 to $7.3 \mathrm{~g} / \mathrm{L}$ in the bioreactor. Simultaneity, in the membrane tank, MLSS increased from 2.11 to $7.71 \mathrm{~g} / \mathrm{L}$.

According to the different MLSS in membrane tank and that in the aeration tank, the circulation ratio, $R$, could be calculated

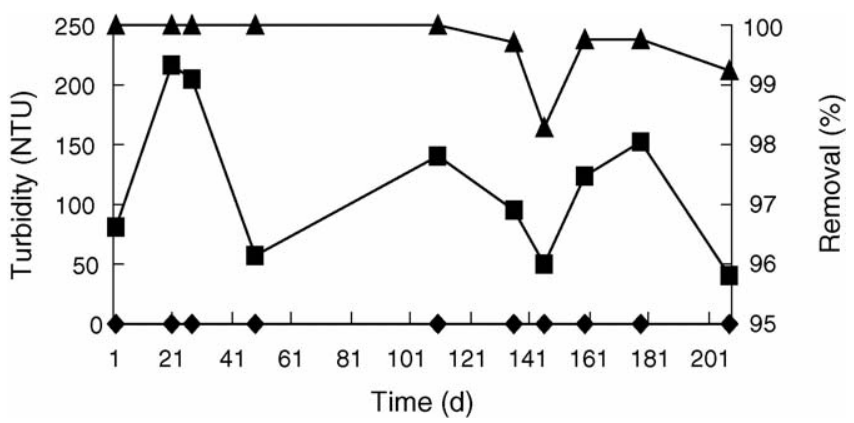

Fig. 6. Variation and removal efficiency of turbidity: effluent; ( $\mathbf{\Delta})$ removal. 


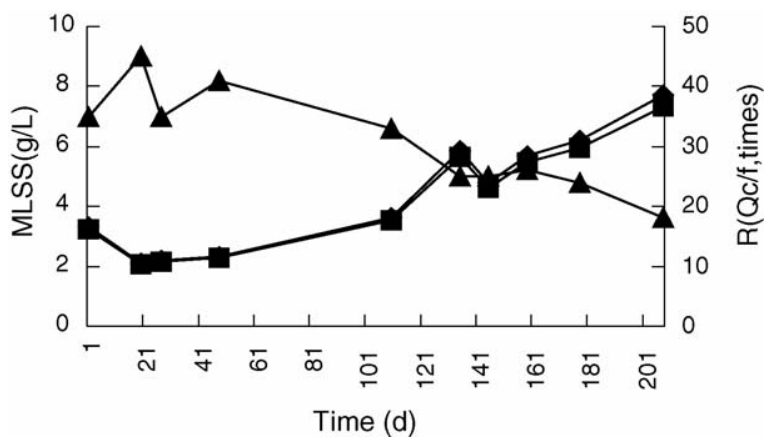

Fig. 7. Variations of $R$ and MLSS in AEC-MBR during operation time: ( $\square$ ) $C_{1}$, MLSS of aeration tank; $(\bullet) C_{2}$, MLSS of membrane tank; $(\boldsymbol{\Delta}) R\left(=Q_{\mathrm{c}} / f\right)$, the circulation ratio, $Q_{\mathrm{c}}$, the circulation flow between membrane tank and bioreactor aeration tank, $\mathrm{m}^{3} / \mathrm{h} ; f$, effluent flow or flux of membrane, $\mathrm{m}^{3} / \mathrm{h}$.

by Eq. (1), which was from 18 to 45 and with an average of 20 in this study. The circulation ratio means the times of the circulation flow to effluent flow of the AEC-MBR. The circulation ratio $R$ is one of the most important parameter for design of the AEC-MBR. The equation for calculation of circulation ratio $R$ was shown as (Eq. (1))

$R=\frac{Q_{\mathrm{c}}}{f}=\frac{C_{1}}{C_{2}-C_{1}}$

where $R\left(=Q_{\mathrm{c}} / f\right)$ is the circulation ratio, times; $Q_{\mathrm{c}}$, the circulation flow between membrane tank and bioreactor aeration tank, $\mathrm{m}^{3} / \mathrm{h} ; f$, effluent flow or flux of membrane, $\mathrm{m}^{3} / \mathrm{h} ; C_{2}$, MLSS of membrane tank, mg/L; $C_{1}$, MLSS of aeration tank, mg/L.

\subsection{Biological characteristics}

Some previous investigators reported that it was difficult to find protozoas and metazoas in MBR system, and the distribution of microbial community was not acted as the mark of sludge healthy and well capability of reactors in MBR
[14-16]. However, in the AEC-MBR, with the domesticating of the inoculated sludge, the sludge became abundant and many species of microorganism were found in the MBR, such as Aspidisca sp., Vorticella sp., Suctoria sp. and Rotifer sp. etc. In addition, with the sludge increasing at $4.0-7.3 \mathrm{~g} / \mathrm{L}$, the Aeolosoma hemprichii sp. was detected which was always survived generally in anaerobic condition (Fig. 8). The important reasons were that there were aerobic zone, anoxic zone and anaerobic zone in the bioreactor and that the circulation of mixed liquid was based on airlift power rather than the circular pump, so the microorganisms were saved and the microbial flocs were maintained well without crush by circular pump. The AEC-MBR was not only fit for growth of microorganism especially for subminiature animals, but also resulted in a favorable condition for nitrification and denitrification (see Section 3.2). In the AEC-MBR, subminiature animals may play an important role in maintaining the sludge healthy, in increasing the treatment capability of the MBR, in improving the filtration property of mixed liquid and the effluent quality.

\subsection{The membrane flux and TMP}

The start-up of the MBR system was carried out by stages. After a 20 days acclimation stage, the operation stage began. The experiment and parameter measurement on the system was lasted for more than 7 months. Fig. 9 represents the variations of flux and trans-membrane pressure (TMP) during the operation period. The flux of membrane was increased step by step from 6 to $13.5 \mathrm{~L} / \mathrm{m}^{2} \mathrm{~h}$, which was higher than the designed value of $10.5 \mathrm{~L} / \mathrm{m}^{2} \mathrm{~h}$. And then, in the whole experiment, the flux maintained stably at $13.5 \mathrm{~L} / \mathrm{m}^{2} \mathrm{~h}$ for more than 5 months, under the TMP at 4-9 kPa.

In this system, the air flowed into the membrane tank was set at 15-20 times to the effluent of the system. Simultaneity, PAC was added to the bioreactor, which did not play a role to

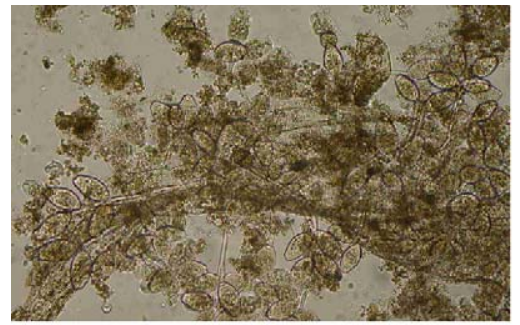

(a)

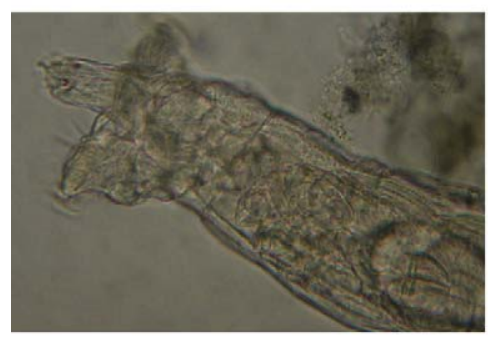

(c)

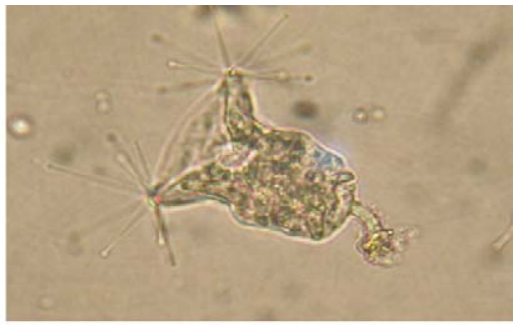

(b)

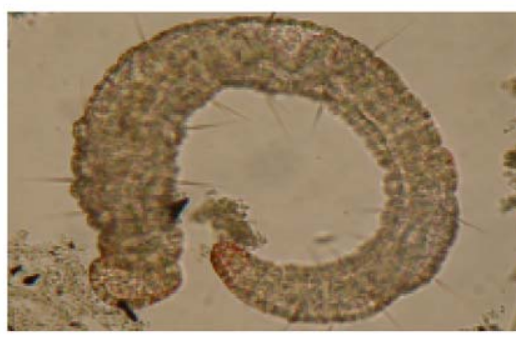

(d)

Fig. 8. Microscope photographs of microorganisms in AEC-MBR: (a) Vorticella community; (b) Suctoria; (c) Rotifer; (d) Aeolosoma hemprichii. 


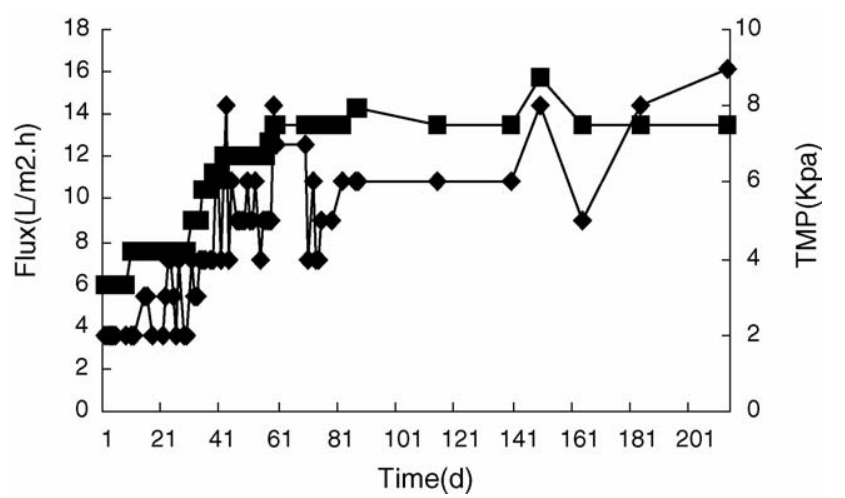

Fig. 9. Variations of flux and TMP during the operation time: membrane; $(\diamond)$ TMP, trans-membrane pressure.

decolorize the treated water but to remove the substances with regard to the membrane fouling. As a result of the operation conditions, the membrane flux was stable at $10.5-13.5 \mathrm{~L} / \mathrm{m}^{2} \mathrm{~h}$ for more 7 months, which was drawn out by the suction pump ( $5 \mathrm{~min}$ on/1 min off). This result showed that the operation condition with air blowing and PAC could prevent the membrane from fouling effectively and that the operation and fouling control modes was very practical and successful in the AEC-MBR.

\subsection{Energy consumption and operational cost analysis}

According to the circulation mode of the AEC-MBR, the energy consumption in the operation of the system was mainly consisted of that from air compressor, raw wastewater pump and suction pump, of which air compressor consumed the most energy. Fig. 10 showed the time-dependent variations of energy consumption with flux of the AEC-MBR.

The energy consumption for air compressor or pumps is calculated as Eq. (2):

$N_{1}=\frac{G P}{3600 \eta}$

where $N_{1}$ is the shaft power of air compressors, $\mathrm{kW} ; G$, the airflow rate, $\mathrm{m}^{3} / \mathrm{h} ; P$, the wind pressure, $\mathrm{kPa} ; \eta$, the available power efficiency of blower, 0.5. Or as Eq. (3):

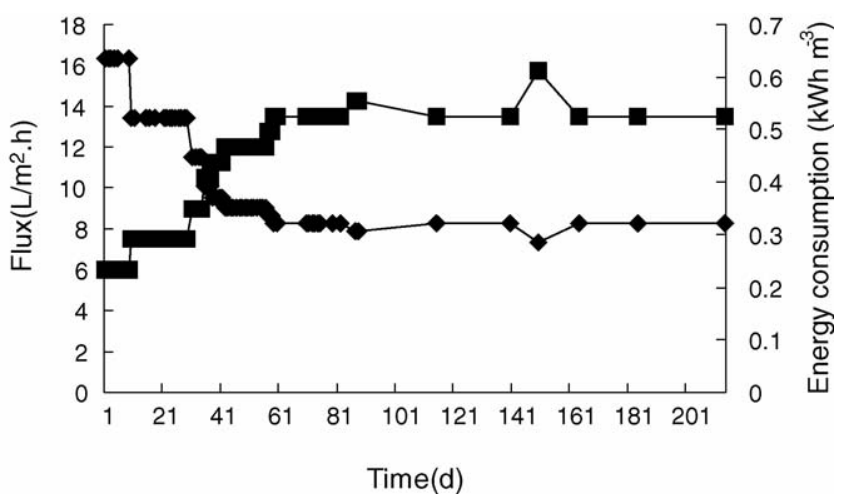

Fig. 10. Variations of flux and energy consumption:

$(\bullet)$ energy consumption
$N_{2}=\frac{9.8 Q H}{3600 \eta}$

where $N_{2}$ is the shaft power of pumps, $\mathrm{kW} ; Q$, permeate flow, $\mathrm{m}^{3} / \mathrm{h} ; H$, the water pressure, $m\left(\mathrm{H}_{2} \mathrm{O}\right) ; \eta$ the available power efficiency of blower, 0.7 .

During the whole operation period, the air rate blown in to the MBR was about $8-10 \mathrm{~m}^{3} / \mathrm{h}$. At the initial stage, the corresponding energy consumption rate was at $0.64 \mathrm{kWh} \mathrm{m}^{-3}$, as the flux of the MBR system was at $6 \mathrm{~L} / \mathrm{m}^{2} \mathrm{~h}$. With the increasing of the flux up to $13.5 \mathrm{~L} / \mathrm{m}^{2} \mathrm{~h}$, the energy consumption rate was reduced to $0.32 \mathrm{kWh} \mathrm{m}^{-3}$. Though the trans membrane pressure increased from 2 to $9 \mathrm{kPa}$ with the increase of flux and membrane fouling, the energy consumption of the pumps was much less than that of the aeration. The percent of energy consumption of the aeration to the total was about $85-94 \%$. Generally speaking, the energy consumption rate is at $2-10 \mathrm{kWh} \mathrm{m}^{-3}$ in the former external MBRs (such as the cross-flow membrane bioreactors) [6] and at 0.2$0.4 \mathrm{kWh} \mathrm{m}^{-3}$ in the submerged MBRs [17]. Compared to that above, the energy consumption of AEC-MBR from 0.64 to $0.32 \mathrm{kWh} \mathrm{m}^{-3}$ was much lower than that of former external MBRs' and was closed to submerged MBRs', especially in the operating stage. The average operational cost was about $\$ 0.11$ / $\mathrm{m}^{3}$ including the total cost of the power active carbon, alkalinity and energy consumption.

In recent years, more than 15 sets of AEC-MBR systems were applied successfully for toilet wastewater treatment and reuse in Beijing and Shanghai in China.

\section{Conclusion}

(1) A new AEC-MBR with $\mathrm{H}$ type circulation pipe on a scale of $10 \mathrm{t} / \mathrm{d}$ was studied and the performance of the MBR was measured for more than 200 days. The measurement results showed that the average removal efficiencies of COD, $\mathrm{BOD}_{5}, \mathrm{NH}_{4}-\mathrm{N}$, color and turbidity were about $90 \%, 99 \%$, $95 \%, 80 \%$ and $99.7 \%$, respectively, and with the average effluent quality of COD $24 \mathrm{mg} / \mathrm{L}, \mathrm{BOD}_{5} 2.4 \mathrm{mg} / \mathrm{L}, \mathrm{NH}_{4}-\mathrm{N}$ $5 \mathrm{mg} / \mathrm{L}$, color $30^{\circ}$ and turbidity $0.2 \mathrm{NTU}$. The effluent quality was better than the requirement of the standards for toilet water reuse in China.

(2) Because of the mixed liquid circulation without circular pump, abundant microorganisms were found in the bioreactor and could play an important role in stable operation of the system.

(3) The maximum flux could maintain stably at $13.5 \mathrm{~L} / \mathrm{m}^{2} \mathrm{~h}$ under the TMP at 4-9 kPa for more than 5 months in the whole experiment period. It showed that in the AEC-MBR, the operation mode for fouling control with air blowing, PAC adding and intermittent working of suction pump was effective and successful.

(4) The energy consumption of the AEC-MBR for reuse of toilet wastewater was about $0.32-0.64 \mathrm{kWh} \mathrm{m}^{-3}$ and the average operational cost was about $\$ 0.11 / \mathrm{m}^{3}$. There were more than 15 sets of AEC-MBR applied successfully in the treatment and reuse of toilets wastewater in China. 
It presents that AEC-MBR is a very practical and economic technology for toilet wastewater reuse.

\section{Acknowledgement}

This research was supported by the fund of State Hi-Tech Research and Development Project of the Ministry of Science and Technology, China (grants 2002AA601220).

\section{References}

[1] Zeeman G, Lettinga GG. The role of anaerobic digestion of domestic sewage in closing the water and nutrient cycle community level. Water Sci Technol 1999;39(5):187-95.

[2] Mian L. A investigation on civilization of water closet in china: 12000 people only have one water closet. http://www.xinhuanet.com/house/ 10djx.htm (accessed May 4, 2005).

[3] Marine Digital Inc., Toilet wastewater treatment system. http://www.marinedigital.com/en/products_sell/rochem /gray.aspgov.za (accessed April 26, 2005).

[4] Zeeman G, Lettinga GG. The role of anaerobic digestion of domestic sewage in closing the water and nutrient cycle community level. Water Sci Technol 1999;39(5):187-95.

[5] Smith CV, Gregorio D, Talcott RM. The use of ultrafiltration membranes for activated sludge separation. In: Proceedings of the 24th annual Purdue industrial waste conference; 1969. p. 1300-10.

[6] Stephenson T, Judd SJ, Jefferson B, Brindle K. Membrane bioreactors for wastewater treatment Alliance House, London: IWA Publishing; 2000.
[7] Tanaka T. Ultrafiltration aids Japanese treatment. Water Qual Int 1997;(7/ 8):26-7.

[8] Copa limits, Copa submerged membrane bioreactor. http://www.copa.co.uk/products/mbr/default.asp. (accessed May 7, 2005).

[9] OAKVILLE, Ontario, ZENON Environmental Inc., Copa submerged membrane bioreactor, March 2, 2001. http://www.zenon.ca/investor/ news_acrhive.shtml (accessed May 7, 2005).

[10] Bentley A, Ballard I. Black and grey water treatment solutions using membrane bioreactors. Nav Architect 2003;35-41.

[11] Sofia A, Ng WJ, Ong SL. Engineering design approaches for minimum fouling in submerged MBR. Desalination 2004;160(1):67-74.

[12] Ueda T, Hata K, Kikuoka Y. Treatment of domestic sewage from rural settlements by a membrane bioreactor. Water Sci Technol 1996;34(9):189-96.

[13] Xu H, Fan Y. Treatment of wastewater from a toilet for reclamation with a airlift external recirculated membrane bioreactor. Environ Sci 2003;24(2):125-9.

[14] Zhang B, et al. Floc size distribution and bacterial activities in membrane separation activated sludge processes for small-scale wastewater treatment/reclamation. Water Sci Technol 1997;35(6):37-44.

[15] Xing CH, Qian Y, Wen XH, Wu WZ, Sun D. Physical and biological characteristics of a tangential-flow MBR for municipal wastewater treatment. Membr Sci 2001;191(1/2):31-42.

[16] Zhang B, Yamamoto K. Seasonal change of microbial population and activities in a building wastewater reuse system using a membrane separation activated sludge process. Water Sci Technol 1996;34(5/ 6):295-302.

[17] Churchouse S. Membrane bioreactors: going from laboratory to large scale-problems to clear solutions. In: Presented at membranes and the environment; 2002. 